\title{
Analysis of winter and summer warming rates in gridded temperature time series
}

\author{
Robert C. Balling Jr ${ }^{1, *}$, Patrick J. Michaels ${ }^{2}$, Paul C. Knappenberger ${ }^{2}$ \\ 'Office of Climatology, Arizona State University, Tempe, Arizona 85287, USA \\ ${ }^{2}$ Department of Environmental Sciences, University of Virginia, Charlottesville, Virginia 22903, USA
}

\begin{abstract}
The Intergovernmental Panel on Climate Change (IPCC) stated in its 1995 report that 'the balance of evidence suggests a discernible human influence on global climate'. The observed nearsurface warming which has occurred in the winter season over the mid-to-high latitudes of the Northern Hemispheric continental areas is used as empirical support for numerical model simulations which suggest a similar pattern of temperature change to occur under conditions of increasing atmospheric carbon dioxide levels. In this work, we investigate, in detail, the seasonal pattern of temperature change as derived from the 2 gridded temperature departure datasets - the IPCC land-based data since 1946, and the MSU (microwave sounding units) satellite-based dataset since 1979. We find that the pattern of temperature trend differentials between winter and summer seasons has not remained constant over the last $50 \mathrm{yr}$, and over the last 2 decades is in less agreement with numerical model simulations. We find a negative correlation between relative winter warming and average winter temperature, which means that winter temperatures are warming the most in colder locations.
\end{abstract}

KEY WORDS: Climate change $\cdot$ Seasonal temperature trends

\section{INTRODUCTION}

While much has been made of the recent statement by the Intergovernmental Panel on Climate Change (IPCC) that 'the balance of evidence suggests a discernible human influence on global climate' (Houghton et al. 1996), little public attention has been tendered towards the actual nature of that influence. In fact, the magnitude, spatial distribution and seasonality of human-induced climate changes are clearly much more important than the mere existence. Humans, for example, have altered the climate of cities and surrounding regions for thousands of years, but no one would argue that the large $\left(1\right.$ to $\left.2^{\circ} \mathrm{C}\right)$ changes that result from the most substantial urbanizations are of enough social significance to warrant remediation.

Similarly, the seasonal distribution of climatic warming can change the effects from benign and/or beneficial to highly deleterious. If warming were primarily a phenomenon during the winter in the coldest air-

\footnotetext{
•E-mail: robert.balling@asu.edu
}

masses, there is minimum social cost and even some benefits with regard to energy consumption. If it primarily occurs in the warmest airmasses during the summer over agricultural regions that are already experiencing moisture stress, then the effects are clearly important and costly.

In both major IPCC assessments of climate change (Houghton et al. 1990, 1996), the projected warming is greatest in the higher latitudes, particularly in the Northern Hemisphere, and greater in the low-sun season than the high-sun season. These same IPCC reports have noted that the maximum observed nearsurface warming has occurred in the winter season over the mid-to-high latitudes of the Northern Hemispheric continental areas. This match between temperature patterns predicted by numerical models and temperature patterns observed in thermometer records has been used by the IPCC as empirical support for the numerical model simulations.

Recognizing the importance of identifying and analyzing the winter versus summer warming signal, we (1) determine winter season and summer season warming rates for the globe using thermometer re- 
cords and satellite-based temperature measurements, (2) examine spatial patterns in winter versus summer temperature changes over various time periods, and (3) compare similarities and differences between the near-surface air temperature patterns and the lowertropospheric temperature measurements from satellites. Our results allow us to assess winter versus summer warming rates, spatial and temporal patterns in the seasonal warming rates, and consistency between the near-surface air temperature patterns and the satellite-based estimates.

\section{DATA ASSEMBLAGE}

Two basic datasets are used throughout this study:

(1) IPCC Near-Surface Temperatures. The IPCC report (Houghton et al. 1996) describes a near-surface temperature dataset that is available on the internet and widely used in climate research. The data begin in 1851 and run through 1995 (with constant updates). During the early part of the record, however, the spatial coverage of the data is extremely limited. The dataset includes both land-based observations as well as sea-surface temperature data.

The land surface air temperatures are taken from the $5^{\circ}$ latitude by $5^{\circ}$ longitude grid cell temperature data developed and described by Jones (1994). Jones carefully assessed the homogeneity and representativeness of each time series from 2961 stations, and every effort was made to identify and eliminate errant values. He converted the monthly station observations into the $5^{\circ}$ latitude by $5^{\circ}$ longitude grid-box data, and all values are expressed as deviations (anomalies) from a reference period defined as 1961 to 1990.

The IPCC temperature data for the oceanic areas were extracted from the sea-surface temperature data generated and described by Folland \& Parker (1995). The original data come from millions of observations from ships, and a physical-empirical method is applied to the raw data to eliminate inhomogeneities that impact the oceanic temperatures.

(2) MSU Lower-Tropospheric Temperatures. Measurements of microwave emissions from molecular oxygen in the lower $8 \mathrm{~km}$ of the atmosphere are made by microwave sounding units (MSU) onboard polar orbiting satellites, and the results provide an excellent measure of lower-tropospheric temperatures (Spencer \& Christy 1990). Microwaves are able to penetrate the atmosphere with little attenuation, and the amount of energy received by the satellites is directly proportional to the temperature in the lower atmosphere. The $53.74 \mathrm{GHz}$ channel is highly sensitive to the thermal emission of molecular oxygen in the middle troposphere, and has little sensitivity to water vapor, the earth surface properties, or cloud variations. The polar orbits of the satellites assure that virtually the entire earth is covered; remote and oceanic areas of the earth are covered as easily as any other part of the planet. These monthly data are available on the internet from 1979 to present for $2.5^{\circ}$ latitude by $2.5^{\circ}$ longitude grid cells; the data are expressed as anomalies with respect to a 10 yr base period $1982-1991$. The $2.5^{\circ}$ cells were combined by simple averaging into $5^{\circ}$ cells to allow direct comparisons with the IPCC temperature data.

Three basic time periods were selected for the analyses presented in this investigation. The longest time period is $100 \mathrm{yr}$, and extends from 1896 to 1995. However, the spatial extent of complete temperature records is very limited over this period. Therefore, a second period of $50 \mathrm{yr}$ was established from 1946 to 1995. Using this time period, the spatial coverage of regions with usable data more than doubles, providing a more complete pattern of temperature trends. It also represents the period of the most rapid anthropogenic greenhouse enrichment of the atmosphere. Finally, the third time period, defined as 1979 to 1995, allows the satellite-based MSU and IPCC databases to be directly compared.

For each calendar year and for each grid cell with $90 \%$ complete data over the selected time period, the mean winter (October-March in the Northern Hemisphere and April-September in the Southern Hemisphere) and mean summer (April-September in the Northern Hemisphere and October-March in the Southern Hemisphere) temperatures were determined. The difference between the two (winter minus summer) was determined for each cell for each year. For each time period selected, a final matrix was constructed with 2592 rows, one for each $5^{\circ}$ latitude by $5^{\circ}$ longitude grid cell, and columns that included (1) latitude of cell center, (2) longitude of cell center, (3) summer temperature anomaly, (4) winter temperature anomaly, (5) winter minus summer temperature anomaly, and (6) the lower-tropospheric temperature (K) for the winter season as determined from the MSU measurements over the period 1982-1991.

\section{RESULTS AND DISCUSSION}

Examples of summer versus winter warming are illustrated in the 1946 to 1995 IPCC data presented in Figs. 1 \& 2. Each figure shows the linear warming rate in ${ }^{\circ} \mathrm{C}$ decade ${ }^{-1}$ over the 50 yr period. The 1291 grid cells available for the summer months reveal a warming of $0.05^{\circ} \mathrm{C}$ decade $^{-1}$ (Fig. 1). The map reveals more warming in the Southern Hemisphere than the Northern Hemisphere, and the map also reveals some cooling in the Northern Hemisphere in areas down- 


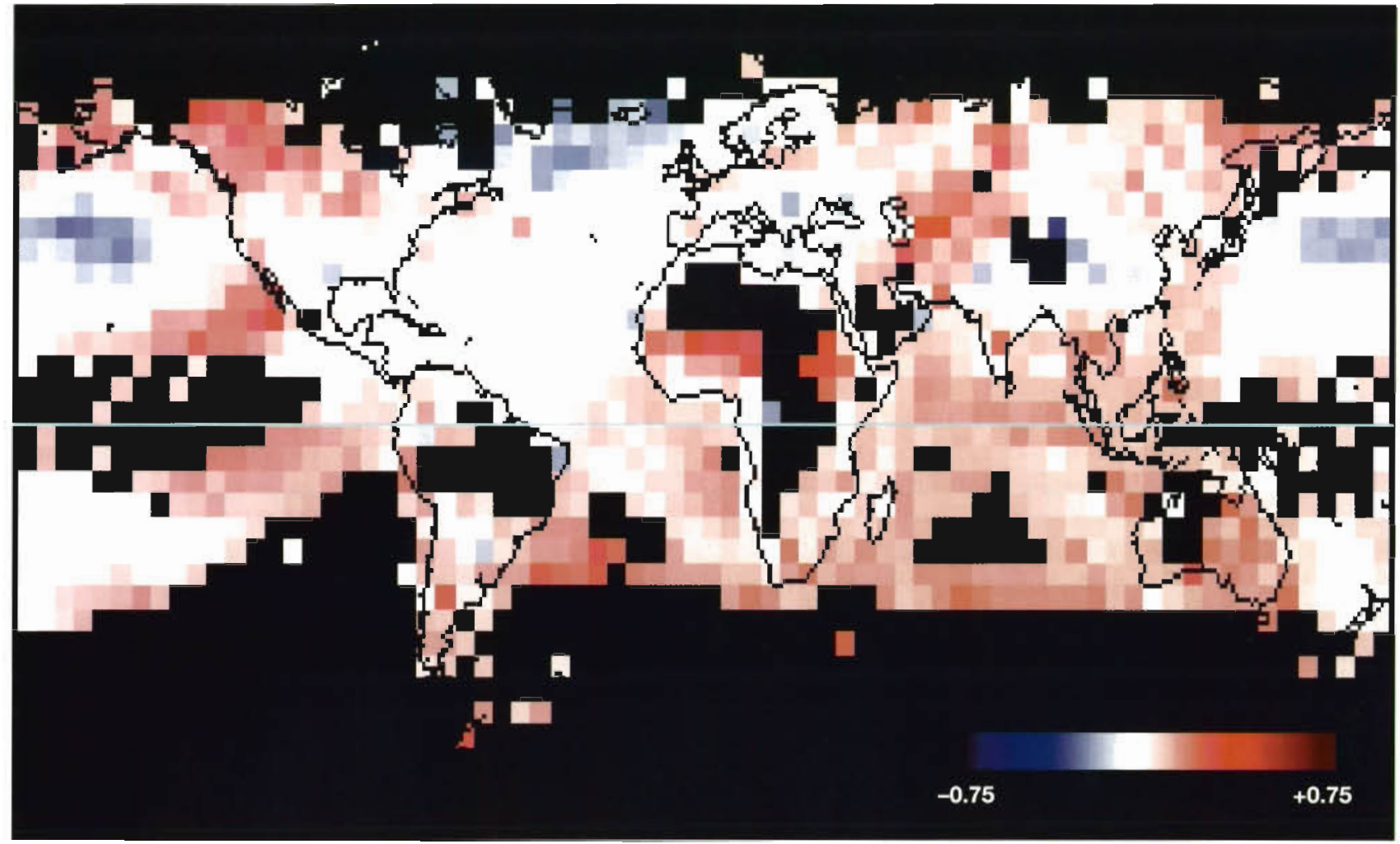

Fig. 1. Summer season temperature trends $\left({ }^{\circ} \mathrm{C}\right.$ decade $\left.{ }^{-1}\right)$ for the IPCC near-surface data over the period $1946-1995$

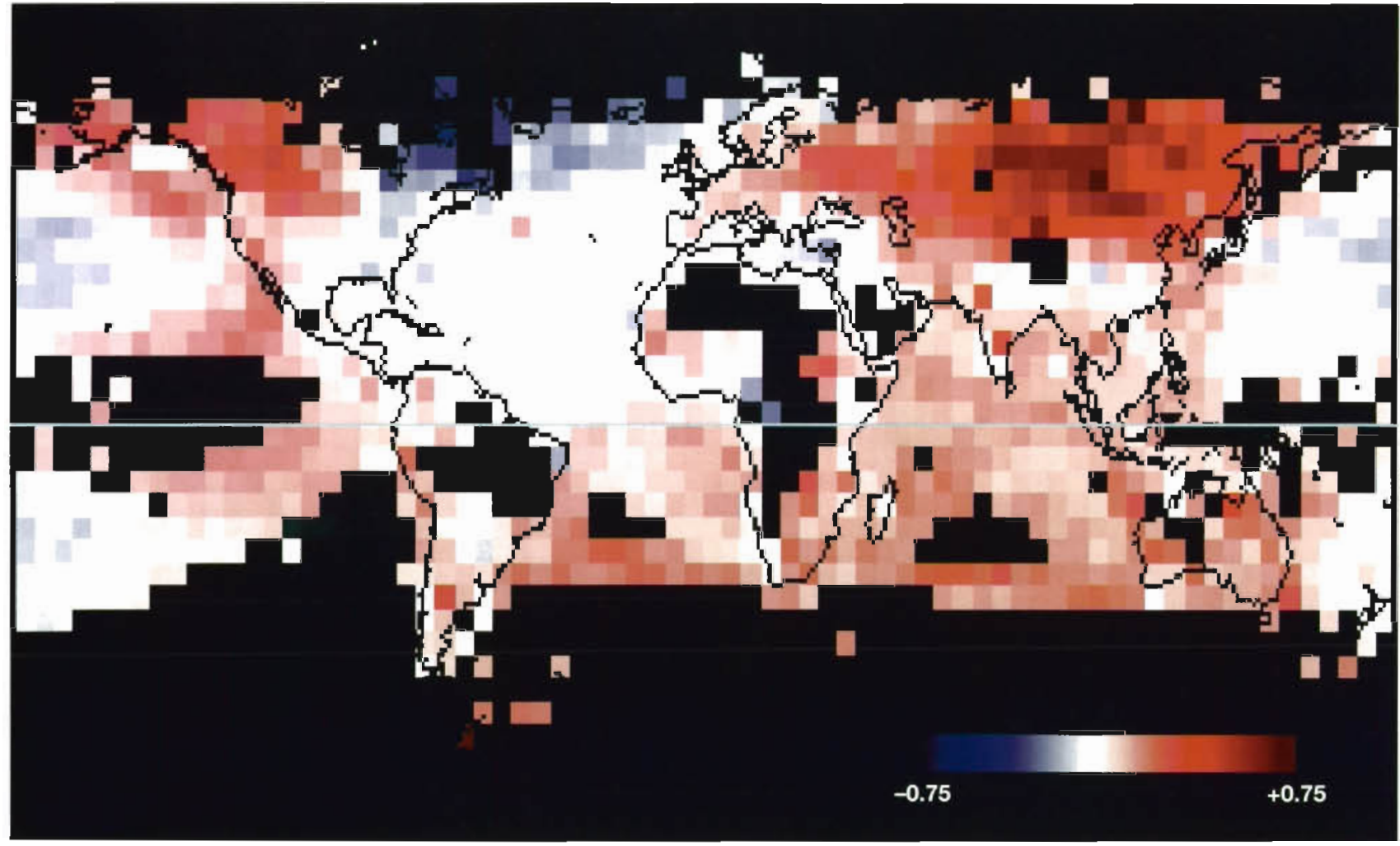

Fig. 2. Winter season temperature trends $\left({ }^{\circ} \mathrm{C}\right.$ decade $\left.{ }^{-1}\right)$ for the IPCC near-surface data over the period $1946-1995$ 
wind of the industrial complexes of North America, Europe, and Asia. The spatial pattern found in the Northern Hemisphere suggests that anthropogenic aerosol sulfates may have reduced warming or even promoted cooling in these downwind areas (e.g. Chin \& Jacob 1996, Houghton et al. 1996, Chuang et al. 1997). The potentially large effect of sulfates during the summer months is consistent with the recent modeling efforts of Mitchell \& Johns (1997) who showed the greatest sulfate-induced climate impacts during the summer season.

The plot of the winter warming rates (Fig. 2) reveals a greater amount of warming overall with a global average of $0.08^{\circ} \mathrm{C}$ decade ${ }^{-1}$; the difference between the summer and winter rates is statistically significant as indicated by a non-zero trend in the difference between summer and winter warming rates. The Pearson product-moment correlation coefficient between the 2 seasonal maps is 0.55 with the largest difference being the pronounced winter season warming apparent in north-central Asia and northwestern North America. A map of the differences in seasonal temperature trends (winter minus summer) further illustrates the strength of the differential trend in central Asia and northwestern North America during this period (Fig. 3). In the mid-to-high latitudes of the Northern
Hemisphere, winters are warming much more quickly than summers over the continental surfaces according to the IPCC database.

The results using the 100 yr temperature record are similar to those using the 50 yr record, even though only 546 grid cells contain at least $90 \%$ available data for the period. The average warming rate for the globe from 1896 to 1995 was $0.05^{\circ} \mathrm{C}$ decade ${ }^{-1}$, with the winter warming rate $\left(0.06^{\circ} \mathrm{C}\right.$ decade $\left.{ }^{-1}\right)$ being slightly greater than the summer rate $\left(0.05^{\circ} \mathrm{C}\right.$ decade $\left.{ }^{-1}\right)$. The spatial pattern of winter minus summer temperature trends (not shown) also shows evidence that the largest values occur in central Asia.

However, when we look at the winter minus summer temperature differences during the more recent period 1979-1995 (when satellite data has been available), a somewhat different pattern emerges, especially over the high latitudes of the Northern Hemisphere. Fig. 4 shows the winter minus summer trend differentials from the 1424 cells available from the IPCC record. The strongest relative winter warming still occurs in central Asia; however, northern latitudes of western and eastern Asia exhibit a relative cooling, as does much of northern North America. A more complete data coverage of these regions is provided by the satellite-based MSU dataset for the same period. Fig. 5

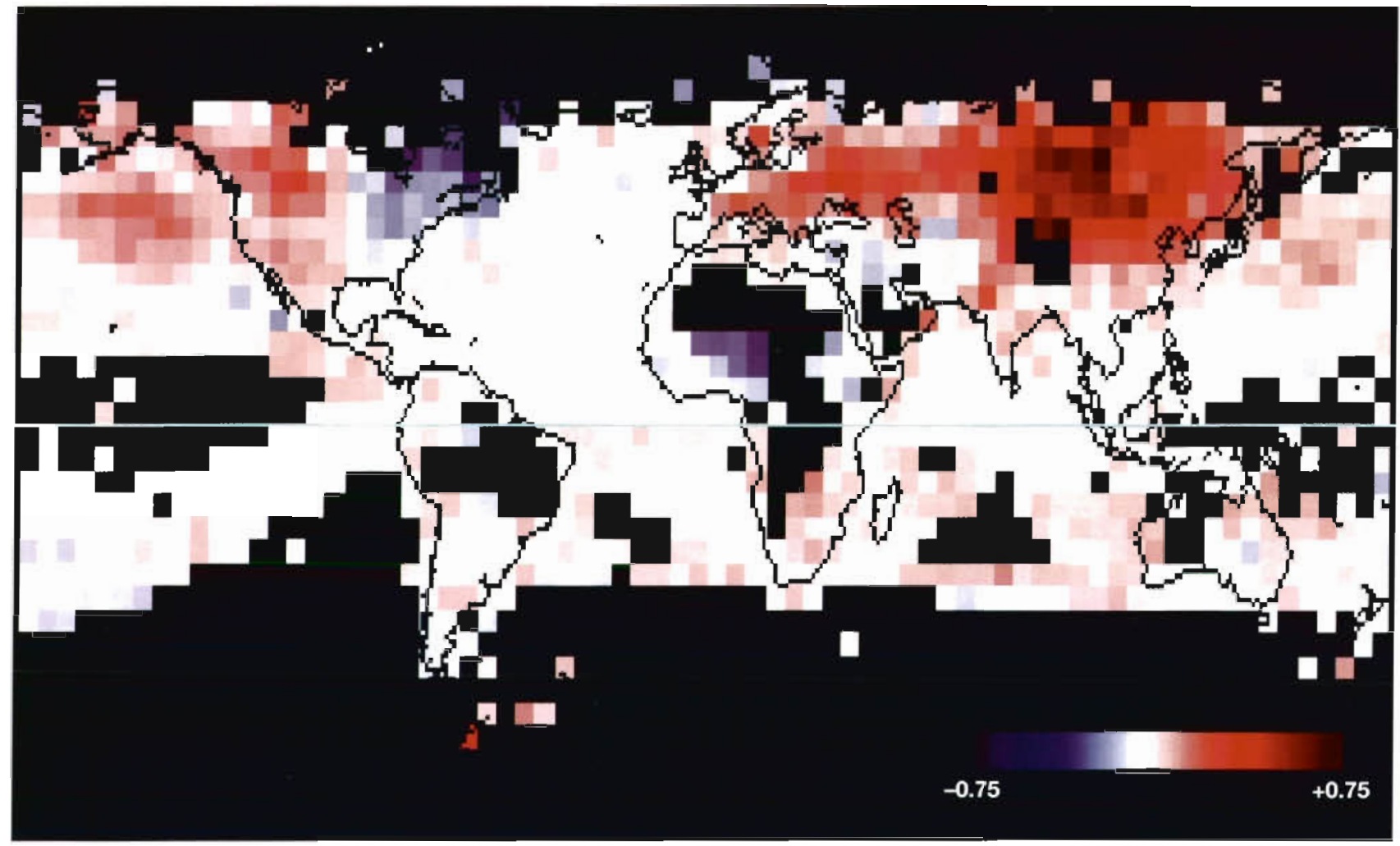

Fig. 3. Seasonal difference (winter minus summer) in temperature trends $\left({ }^{\circ} \mathrm{C}\right.$ decade ${ }^{-1}$ ) for the IPCC near-surface data over the period 1946-1995 


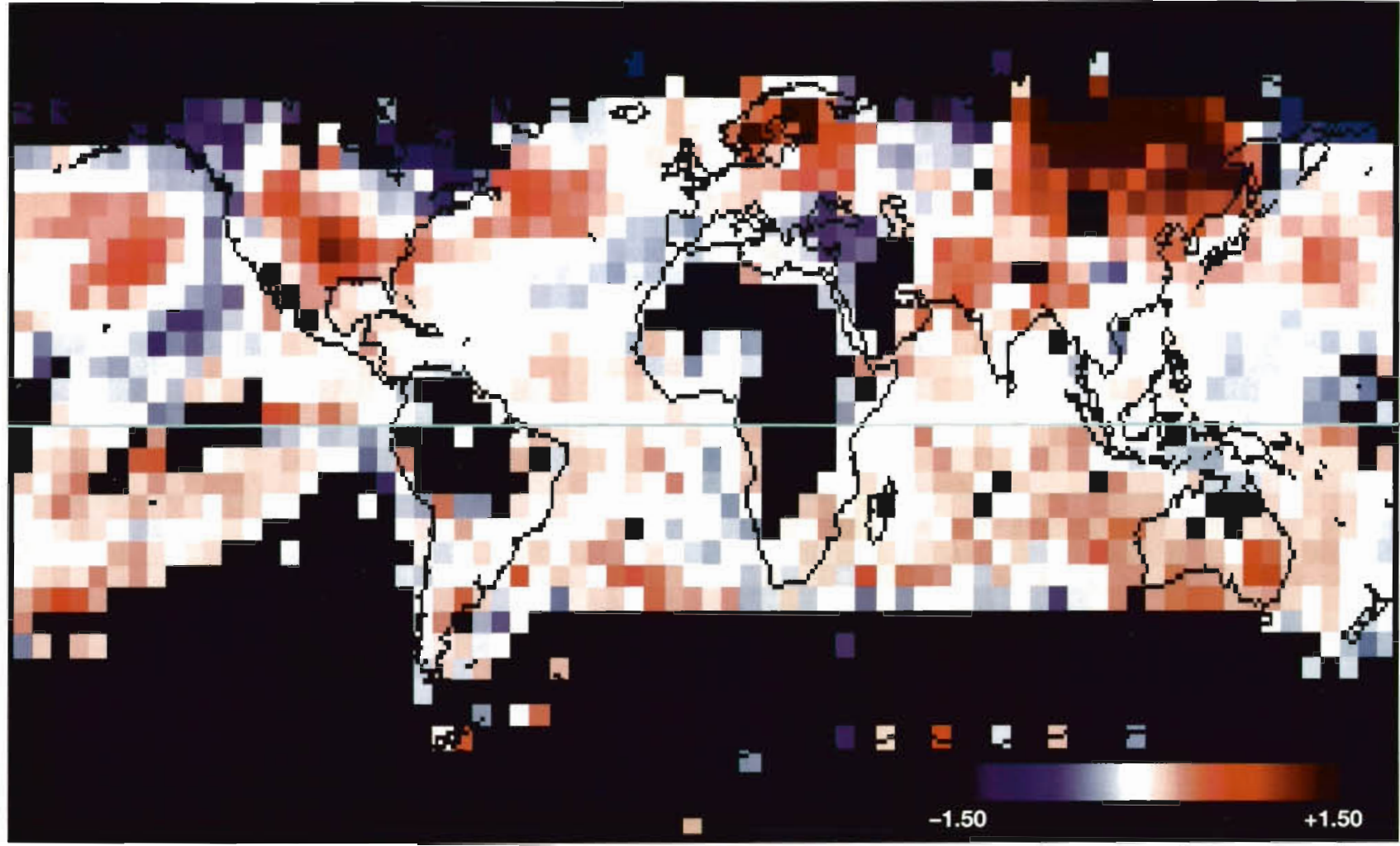

Fig. 4. Seasonal difference (winter minus summer) in temperature trends $\left({ }^{\circ} \mathrm{C}\right.$ decade $\left.{ }^{-1}\right)$ for the IPCC near-surface data over the period 1979-1995

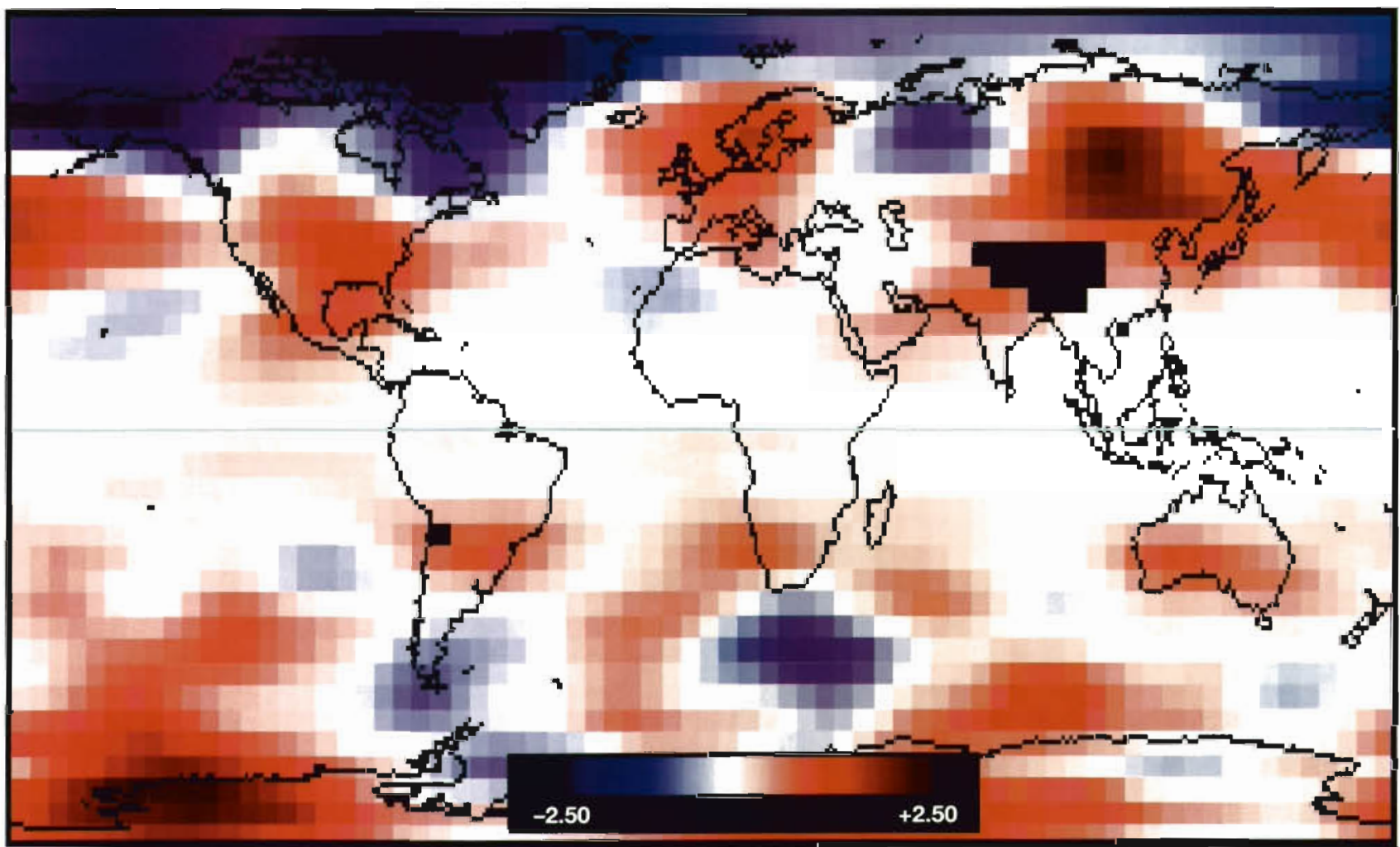

Fig. 5. Seasonal difference (winter minus summer) in temperature trends $\left({ }^{\circ} \mathrm{C}\right.$ decade $\left.{ }^{-1}\right)$ for the satellite-based MSU data over the period 1979-1995 
shows the winter minus summer trend differentials in this record. The satellite data confirm that the region of maximum relative winter warming is in central Asia, with a band of relative warming extending across the northern temperate latitudes. These data also exhibit the relative winter cooling over most of the Northern Hemisphere high latitudes, especially prominent over eastern and western North America. This pattern, observed in both the surface-based IPCC record and the satellite-based MSU record, is not consistent with the IPCC global climate model projections in which the greatest amount of relative winter warming is over northern North America and northern Eurasia (Houghton et al. 1996, p. 307).

It is interesting to note that studies which attempt to find a 'fingerprint' of global warming by looking at the correspondence between observed patterns of temperature change and modeled patterns of temperature change (e.g. Santer et al. 1996) find strong similarities using data only from 1963-1987. As our analysis reveals, this was a period when the pattern of temperature departures was rather similar to the modeled results. However, as pointed out by Michaels \& Knappenberger (1996) when data are included through 1995, the 'fingerprint' becomes smudged as the pattern correlation between observations and model projections drops to near zero. The reasons for this are obvious in this analysis by comparing the patterns of the more recent period with the patterns from 1946 to 1995. The relative winter cooling in the high latitudes of the Northern Hemisphere, observed in the 1979 to 1995 period, does not fit GCM (general circulation model) expectations (e.g. Houghton et al. 1996) and thus leads to a reduced pattern correlation.

The spatial patterns in winter minus summer temperature trends were further broken down into land versus ocean areas. As described in Table 1, winter is warming faster than summer for all areally averaged temperature data, irrespective of starting date, land versus ocean areas, or satellite-based versus near-surface thermometer measurements. The land areas have a statistically significantly greater winter minus summer differential trend than the ocean areas irrespective of starting date or satellite-based versus near-surface thermometer measurements. This pattern of relative winter warming over land areas is consistent with Wallace et al. (1996) and Hurrell \& Trenberth (1996) who find that circulation patterns during the past several decades have resulted in a surface temperature anomaly pattern of warming over the land areas and cooling over the oceans in the Northern Hemisphere.

Finally, the differential temperature trend values were compared to the tropospheric temperatures. As seen in Table 1, a negative Spearman rank-order correlation coefficient is determined for all differential
Table 1. Descriptive statistics for winter minus summer temperature trends. Means and standard deviations are in ${ }^{\circ} \mathrm{C}$ decade $^{-1} ; r_{\text {temp }}$ is the Spearman rank-order correlation coefficient with winter season lower tropospheric temperatures. Correlation coefficients in italics are significant at the 0.05 level of confidence

\begin{tabular}{|lrrrr|}
\hline Variable & Mean & $\begin{array}{c}\text { Standard } \\
\text { deviation }\end{array}$ & $\mathrm{N}$ & r $_{\text {lemp }}$ \\
\hline 1946-1995 IPCC: & & & & \\
Globe & 0.04 & 0.14 & 1271 & -0.32 \\
Land & 0.06 & 0.17 & 725 & -0.41 \\
Ocean & 0.00 & 0.06 & 546 & -0.12 \\
1979-1995 IPCC: & & & & \\
Globe & 0.05 & 0.46 & 1405 & -0.10 \\
Land & 0.09 & 0.57 & 735 & -0.11 \\
Ocean & 0.01 & 0.30 & 670 & -0.10 \\
$1979-1995 \mathrm{MSU}:$ & & & & \\
Globe & 0.06 & 0.86 & 2575 & -0.10 \\
Land & 0.15 & 0.79 & 891 & -0.10 \\
Ocean & 0.02 & 0.89 & 1684 & -0.03 \\
& & & & \\
\hline
\end{tabular}

trends and the tropospheric temperature values; all but one of the coefficients is statistically significant. The relationship is consistently stronger over land than over the oceans. Basically, the colder the winter environment, the greater the winter minus summer differential trend. However, notice that the strength of this association is diminished in the more recent time interval which is consistent with our results of relative winter cooling in the northern high latitudes in recent decades.

\section{CONCLUSIONS}

The patterns of temperature trends over the globe have been changing over time and space. The difference between winter and summer temperature trends shows that for the last 2 decades, the pattern has not been totally in keeping with the modeled projections using GCMs combining the effects of increasing carbon dioxide and sulfate aerosols. Most of the high latitude regions of the Northern Hemisphere have shifted from exhibiting a relative winter warming to now showing a cooling in the winter with respect to summer. However, one region of the globe shows both a very large and a very consistent relative winter warming-north-central Asia. The warming in this region is present in every time period chosen and in both the IPCC and satellite records. This area is a source region of the Siberian cold anticyclone. That the warming is predominantly in these airmasses is likely to be a consequence of their extreme coldness and consequent dryness. Because these airmasses have very little of a background water vapor greenhouse effect, 
increases in carbon dioxide are very effective at rapidly increasing infrared absorption in the bands where carbon dioxide and water vapor would normally overlap. We note the recent study of Ross et al. (1996), in which the winter:summer ratio of radiosondemeasured warming in Siberia was approximately 4.2:1. Additionally, decadal and longer scale circulation changes may also be partly responsible for the winter warming over these regions.

Nonetheless, a climate change predominately characterized by winter warming of some of the world's coldest airmasses is not likely to be considered disastrous, regardless of the cause. This finding, instead, adds further support to the emerging hypothesis that the earth's climate is not necessarily changing in a deleterious fashion. Growing seasons are lengthening (Thomson 1995, Myneni et al. 1997), crops yields are improving (Wittwer 1995, Nicholls 1997), and forest biomass is increasing (Kauppi et al. 1992). These changes may bear, at least in part, a fingerprint of human activity, and thus lend further support to the IPCC statement that 'the balance of evidence suggests a discernible human influence on global climate.'

\section{LITERATURE CITED}

Chin $M, J$ acob DJ (1996) Anthropogenic and natural contributions to tropospheric sulfate: a global model analysis. J Geophys Res 101:18691-18699

Chuang CC, Penner JE, Taylor KE, Grossman AS, Walton JJ (1997) An assessment of the radiative effects of anthropogenic sulfate. J Geophys Res 102:3761-3778

Folland CK, Parker DE (1995) Correction of instrumental biases in historical sea surface temperature data. Q J R Meteorol Soc 121:319-367

Houghton JT, Jenkins GJ, Ephraums JJ (eds) (1990) Climate

Editorial responsibility: Chris de Freitas,

Auckland, New Zealand change: the IPCC scientific assessment. Cambridge University Press, Cambridge

Houghton JT, Meira Filho LG, Callander BA, Harris N, Kattenberg A, Maskell K (eds) (1996) Climate change 1995: the science of climate change. Cambridge University Press, Cambridge

Hurrell JW, Trenberth KE (1996) Satellite versus surface estimates of air temperatures since 1979. J Clim 9:2222-2232

Jones PD (1994) Hemispheric surface air temperature variations: a reanalysis and an update to 1993. J Clim 7: $1794-1802$

Kauppi PE, Mielikainen K, Kuusela K (1992) Biomass and carbon budget in European forests, 1971-1990. Science 256:70-74

Michaels PJ, Knappenberger PC (1996) Human effect on global climate? Nature 384:522-523

Mitchell JFB, Johns TC (1997) On modification of global warming by sulfate aerosols. J Clim 10:245-267

Myneni RB, Keeling CD, Tucker CJ, Asrar G, Nemaini RR (1997) Increased plant growth in the northern high latitudes from 1981 to 1991. Nature 386:698-702

Nicholls N (1997) Increased Australian wheat yield due to recent climate trends. Nature 387:484-485

Ross RJ, Otterman J, Starr DOC, Eliott WP, Angell JK, Susskind J (1996) Regional trends of surface and tropospheric temperature and evening-morning temperature difference in northern latitudes: 1973-93. Geophys Res Lett 23 $3179-3182$

Santer BD, Taylor KE, Wigley TML, Johns TC, Jones PD, Karoly DJ, Mitchell JFB, Oort AH, Penner LE, Ramaswamy V, Schwartzkopf MD, Stouffer RJ, Tett S (1996) A. search for human influences on the thermal structure of the atmosphere. Nature 382:39-46

Spencer RW, Christy JR (1990) Precise monitoring of global temperature trends from satellites. Science 247:1558-1562

Thomson DJ (1995) The seasons, global temperature and precession. Science 268:59-68

Wallace JM, Zhang Y, Bajuk L (1996) Interpretation of interdecadal trends in Northern Hemisphere surface air temperature. J Clim 9:249-259

Wittwer SH (1995) Food, climate and carbon dioxide. CRC Press, Boca Raton, FL

Submitted: May 8, 1997; Accepted: July 28, 1997

Proofs received from author(s): October 1, 1997 